International Review of Research in Open and Distributed Learning Volume 17, Number 5

September - 2016

\title{
Online Professional Skills Workshops: Perspectives from Distance Education Graduate Students
}

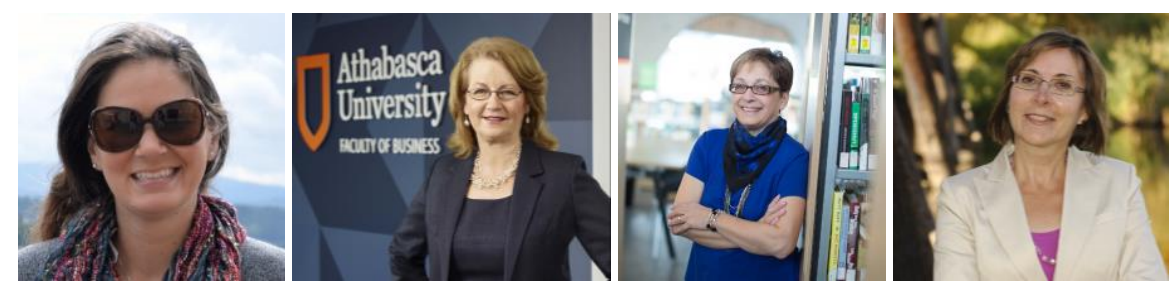

Sarah Gauvreau ${ }^{1}$, Deborah Hurst ${ }^{2}$, Martha Cleveland-Innes ${ }^{2}$, and Pamela Hawranik ${ }^{2}$ ${ }^{1}$ Contact North | Contact Nord, ${ }^{2}$ Athabasca University

\begin{abstract}
While many online graduate students are gaining academic and scholarly knowledge, the opportunities for students to develop and hone professional skills essential for the workplace are lacking. Given the virtual environment of distance learning, graduate students are often expected to glean professional skills such as analytical thinking, self-awareness, flexibility, team-building, and problem-solving inherently through informal means (Cleveland-Innes \& Ally, 2012). The goal of this study was to evaluate the experiences of online graduate students participating in synchronous online professional skills workshops. Students attended the sessions from the various graduate programs at an online Canadian university. The discussions from the focus group held at the end of the project were used to achieve the research goals. This paper used a phenomenological lens to accomplish its research goals. The participants reported that they experienced a "sense of community" and learned skills that were not included in their academic programs.
\end{abstract}

Keywords: professional skills development, synchronous online workshops, distance education, online graduate student

\section{Introduction}

Online graduate student enrolment is steadily increasing on a yearly basis. In their annual report, Allen and Seaman (2007) stated 468685 graduate students enrolled in online courses in the fall of 2006. In their latest report (2016) they found the occurrence of graduate students taking online courses grew to 966307 in 2014, an increase of nearly half a million students. This growth stems from the advantage of 
course flexibility, where students are able to take courses from any desired location and can progress through the material at their own convenience, in addition to learners being able to manage their studies around work and family life. While many online graduate students are gaining academic and scholarly knowledge, the opportunities for students to develop and hone professional skills essential for the workplace are lacking. Professional skills can vary from leadership skills to proficiencies in communication, teamwork, or interpersonal strategies. The Canadian Association of Graduate Schools (CAGS, 2012) attests that professional skill development includes the attainment of such soft skills that can be transferred to a broader context where students are able to present themselves professionally and can "integrate quickly into complex workplace environments after graduation" (pg. 4). A report produced by a commission of university and business leaders indicate that "employers are seeking, along with requisite content knowledge, such workplace skills as professionalism and work ethic, oral and written communication, collaboration and teamwork, and critical thinking and problem-solving, along with innovative and entrepreneurial thinking and the ability to contribute to multidisciplinary teams" (Council of Graduate Schools and Educational Testing Service, 2012). It is up to each university to provide such professional skills development; however, few universities appear to provide graduate students with professional skills development opportunities in their academic programs (Hurst, Cleveland-Innes, Hawranik, \& Gauvreau, 2013). Given the virtual environment of distance learning, graduate students are often expected to glean professional skills such as such as self-awareness, advanced communication skills, flexibility, team-building, and problem-solving through informal means of their course work (ClevelandInnes \& Ally, 2007). However, to provide professional skill building experiences, institutions need to offer formal opportunities, such as workshops, with the objective to prepare "graduates both personally and professionally to support their individual academic to work-life transition" (Canadian Association of Graduate Schools [CAGS], 2008, pg.8).

The purpose of this study was to evaluate the experiences of the graduate students who participated in at least one synchronous online professional skills training workshop made available to graduate students of various disciplines to complement their academic studies and to assist in their preparation for today's workplace environment. This paper used a phenomenological lens to facilitate the analysis. The research questions investigated were: What are the experiences of online graduate students participating in synchronous online professional skill develop workshops? What themes emerge from the online professional skills workshop experiences of online graduate students? What are the contexts of these experiences? What is the overall essence of experience from the workshops of the online graduate students?

\section{Background}

Brick and mortar institutions of higher education are realising the importance of providing professional skill development opportunities for its graduate students that complement academic training. With mounting pressure from provincial and federal governments to strengthen and retain "the highly skilled people needed to thrive in a knowledge-based economy" (CAGS, 2008, pg. 2) universities are putting greater emphasis on developing competencies that were traditionally marginalized for highly valued "hard" skills. It has been well established throughout the literature the significance of proving professional development skills concurrently with graduate programming (Andrews \& Higson, 2008; De Villiers, 2010; Dvorak, 2007; Rubin \& Dierdorff, 2009; Winter, 2002). For example, University of British 
Columbia's Sauder School of Business and the University of Western Ontario's Richard Ivey School of Business Master of Business Administration (MBA) programs are prioritizing professional skills such as leadership, interpersonal skills and change management, to meet the demands of the changing world economy and to enhance their student's employability (Lawrence, 2012). Furthermore, Canadian universities such as York University, University of Saskatchewan, and the University of Ontario Institute of Technology are providing extracurricular options for graduate students to obtain professional skills in the form of on-campus workshops. According to their websites these workshops assist students to cultivate their professional skills to assist in the assimilation into the workforce after graduation. They boast that the skills learned through the workshops offered are directly applicable to a wide range of careers both within and outside of academia. For example, York University offers its on-campus graduates a Writing Success workshop, Career Pathways and Options workshop, while the University of Saskatchewan offers workshops on four broad areas: Leadership and Management, Communication and Teamwork, Entrepreneurship and Career Development, and Reflection on Practice (University of Saskatchewan, 2016; York University, 2016).

CAGS has been integral in bringing forth the importance of providing professional skills development for graduate students. In their 2012 report, CAGS reiterates that Canadian universities need to address the training needs of graduate students to strengthen key skills and competencies compulsory in today's workplace. The report emphasises that professional skills training should be a priority, stating:

Professional skills training for graduate students is essential, indeed an ethical imperative, if universities are to ensure that graduate students are fully trained in ways that will ensure the mobilization of their knowledge and skills and the realization of their potential in a variety of workplace settings - whether academic, for-profit or not-for-profit. GSPD programming should be prioritized by universities - through vision statements, strategic plans, public relations materials, and other mechanisms linked to institutional identity (pg. 31).

As indicated, there is ample information on the worth of providing professional skills for graduate students who are studying in a face-to-face context; however, there is a noticeable gap in the literature relating to the needs of graduate students studying online. In 2009, Athabasca University's Faculty of Graduate Studies (FGS) and the Graduate Students Association (GSA) studied the needs of this unique student body. Surveying 699 of its online graduate student population, they endeavoured to learn about preferences for existing and new educational supports, learning community, and professional development opportunities (Hawranik \& Chernish, 2009). When students were asked what they believed would improve their graduate student experience, education, and professional development, they pointed to a series of skill building workshops. The top example cited by students dealt with different aspects of academic writing and proper referencing $(n=623,89 \%)$. A second area of great importance cited dealt with gaining help with career and personal management issues, such as managing time better $(\mathrm{n}=479$, $68.5 \%)$, writing an effective curriculum vitae ( $\mathrm{n}=558,78 \%)$, as well as obtaining help with other things such as aptitude, ability, career skills assessment, interviewing skills, effective presentations, decisions, time management, leadership, and dealing with compteting demands to name a few (Hawranik \& Chernish, 2009). 
Some researchers have argued that such skills as interpersonal, verbal, communication, and leadership skills, cannot be taught through online learning (Razali, Syamimi \& Yahya, 2010). However, a study by Cleveland-Innes and Ally (2007), investigated the use of utilizing two e-learning platforms to create effective learning outcomes in the workplace, finding there is "potential for soft skill development and affective gain using online delivery" (para. 1). Furthermore, Hurst and Thomas (2008) illustrate what is achievable in teaching online team training and team skills practice for an online MBA program. They found that using an online platform to deliver teaming and interpersonal skills was "not only effective in developing competency in social interaction, but that online learning may in fact be the superior method" (para. 4).

Our study's objective was to address the professional skill needs of the online graduate students at Athabasca University (AU) and provide them with formal opportunities to obtain and hone these skills that complement their disciplinary expertise and facilitate workplace readiness and workplace efficacy. In order to accomplish this, we designed and developed a series of workshops based on the 2009 FGS survey that indicated the areas of need outlined by AU graduate students. The data from the focus group at the end of the study is reported in this paper.

\section{The Workshops}

Using sound instructional design priciples, three sychronous online workshops were designed, developed, and offered as a result of the 2009 FGS suvery that included academic writing, career development, and personal management strategies. Initally, only one session of each of the three topics was offered, with a cap of thirty students; however, demand was so high that a second round of workshops was offered to accommodate the number of students on the waiting list. The workshops were delivered by various AU faculty and graduate students via the webconferecing system Elluminate Live!, and were approximately three hours in length. All of the workshops were offered synchronously and included audio and video components and active participation. The workshops were offered on Saturday mornings to enable greater access for students who were working during the week.

Putting the academic into academic writing. This workshop aimed to provide an understanding of the role critical thinking plays in both academic and workplace writing. It offered a set of strategies to use when developing and critiquing an argument, that not only assists academic writing, but those who will write as part of their profession, for example managers. Videos and exercises were used by the facilitator to encourage discussion, analytical thinking, and writing skills, in addition to providing opportunities to work with peers to implement writing strategies.

Life after graduation: Career planning and preparation. The goal of this workshop was to assist graduate students with self-exploration and provide them with the tools for goal setting. In addition, this workshop facilitated discussion on effective occupation search techniques, networking and interpersonal skills, and a demonstration on how to create a virtual portfolio for the workplace.

Personal management strategies: Work/life/study balance. This workshop was developed using a change management framework applied at the individual level. Discussion on personal 
experiences during their educational journey, sharing of coping strategies, and techniques to create a better work/study/life balance occurred.

\section{Methodology}

The project involved a prospective design with pre and post online surveys taking place with each workshop and a focus group at the end. All AU graduate students in a master's or doctoral program were eligible to participate in the study. Advertisements were posted on the Faculty of Graduate Studies website and the websites of all of the programs. Students had to register for the workshops and agree to attend at least one workshop and complete the pre- and post-survey for that workshop.

Participating students were invited to attend a focus group after completion of the workshops. The results of the survey questions guided the researchers to formulate questions for the focus group that clarified the experiences identified in the data derived from the surveys. The focus group discussion explored student perceptions of the value of the workshops, the effect on their sense of learning community and the degree to which they felt their skills were enhanced. Questions were formulated in order to understand the experience of distance learners and the meaning they made of their experiences (Cain, Marrara, Pitre, \& Armour, 2003). Open-ended questions were used in the focus group to elicit rich responses. This technique offered the interviewer the opportunity to probe issues and obtain feedback (Cain et al, 2003). The focus group took place two weeks after the last workshop was offered and the interviews were conducted and recorded via Adobe Connect web conferencing software for the duration of approximately 90 minutes. Appendix A provides a complete list of the interview questions utilized.

The transcendental phenomenology approach was employed as it consisted of identifying a phenomenon to study, "bracketing out one's experiences and collecting data from several persons who have experienced the phenomenon" (Creswell, 2007, pg. 60). In a phenomenological study, individuals must all have experienced the phenomenon being explored; therefore, the participants in this study are online graduate students, from various programs, studying at the same open university, and who participated in at least one online professional skill development workshop.

\section{Data Analysis}

The transcendental phenomenological approach was employed consisting of the reduction of the data collected into significant statements or quotes and merging these statements into themes. The following analysis used the procedures of data managing, reading, memoing, describing, classifying, interpreting, and representing as outlined by Creswell (2007, pp. 156-157).

\section{Data Managing}

The initial phase of analysis for this phenomenology study consisted of the creation and organization of data into word document files. The recording from the focus group was obtained and transcribed into a word document format in preparation of the next step, reading and memoing. The subsequent step included reading and reviewing the text that was previously organised to acquire an overall feeling of the student's workshop experience. Note making and the formation of initial codes were also executed. 


\section{Describing}

In part of the phenomenological analysis process, a personal experience description of the phenomenon under study was required to "bracket" any presuppositions and biases, so that the researcher can be conscious of them through all phases of the research and therefore minimise their influence on the findings (Creswell, 2007). With this in mind, the first author noted her own experiences participating as an online graduate student in a professional skill development workshop.

Personal Experience. The first author of this paper was an online graduate student pursuing her Master of Education (specializing in Distance Education) degree at the time of the study. She could identify with many of her online colleagues the challenges of studying in a distributed learning environment and the importance of trying to glean as many professional skills to use in the workplace as possible. Prior to the workshops, the author felt that there was a lack of opportunity available to develop and enhance professional skills, skills that would be able to be developed in face-to-face institutions, such as public speaking and even leadership and instructional opportunities that coincide with Teacher Assistant (TA) responsibilities. However, with the introduction of the workshops offered in this study, the author felt a void had been filled in the online academic environment, especially for the unique group of students studying at the graduate level. With that said, it is important to note that this author had a differing role in the workshops than the participating students and thus experienced them with a facilitator lens versus a participant lens, eliminating any bias as a participant.

\section{Results}

Significant statements from the focus group are highlighted and reported in Appendix B to provide an understanding of how participants experienced professional skill building during the online workshops. Of the 61 participants of the study, 10 attended the focus group. Below is the breakdown of the demographics:

- two male and eight female

- $\quad$ Average age was 43.4

- $30 \%$ or three participants were from the Business Administration program

- $50 \%$ or five participants were from the Education program

- $10 \%$ or one participant was from the Health Sciences program

- $10 \%$ or one participant was from the Physiology program

\section{Interpreting}

This phase of the phenomenological analysis involved grouping the significant statements into meaningful units and providing a textual description of what was experienced, a structural description of how it was experienced, and finally, an explanation of the essence of the experience that represented the culminating aspects of this study (Creswell, 2007). 
Textual description. Two major themes emerged. The first was a sense of community created by means of the real time student interaction amongst the online grad students, not only within the same program, but throughout various disciplines. The second theme focused on the student's learning experience in attaining soft and professional skills.

Sense of Community through Synchronous Interaction. With numerous analogous comments expressed by the participants, it was evident that many who attended the virtual workshops experienced a shared sense of community. Participant A noted this by stating: "For me being a part of these workshops made me realize that I am part of a bigger part of the community of people with all kinds of skills and abilities and help that I can access." It was articulated that the use of synchronous communication allowed the participants to connect and share with others. Participant B explained this by stating: "I would say from the first time we were together there was a real connect for me, um, with other people, it was a really positive." This comment reiterated the profound desire of online students to bond with others to achieve a community of learning. The lack of "live" social interaction in online graduate courses heightened the communal element of the workshops, where students were able to converse and interact in real time with other students. Not only was camaraderie felt among students, some also expressed that they learned from others and were able to benefit by sharing practical knowledge and experiences. For example, Participant $\mathrm{C}$ wrote: "I also really benefitted from talking to others who have work experience in the field and who were able to give some advice in the small group portion of the career workshop." Participant B said: "I feel like I've had the opportunity to work with and learn alongside some very interesting and accomplished students." It was evident that students are looking to form relationships with others and share and compare experiences in their studies. This was further demonstrated by the comment from Participant A: "I think what helped me in the workshop were the ability to link with other people who were having similar types of experiences along the way...." These comments exemplified that through the attendance of the online workshops, participants who were learning at a distance autonomously, experienced a sense of belonging in a community of learners.

Attaining soft and professional skill sets. The second theme that emerged from the participant's comments focused on their learning experience in attaining soft and professional skills via the online workshops. A number of the participants found the workshops helpful and gleaned new information and skills that were not otherwise instructed in their program courses. For example, Participant D writes: "The information learned in APA will continue to 'haunt' me as I write each assignment and paper" and "I feel the writing workshop has provided me with additional skills to write more academically." Not only did some of the participants find the information presented in the workshops helpful, many put into practice what they learned and saw direct results. Participant E stated: "Clarity for me on writing for the program was helpful, my post course marks are up and my time to write the papers is down." Participant A commented: "[The workshops] helped me to reorient my writing" and Participant E exclaimed "I am using the referencing section from the academic writing workshop." Not only did the participants garner professional skills from the workshops, they openly acknowledged the importance of developing these competencies outside of the academic realm. 
I learnt something beyond my course work, beyond my courses in the MBA program, beyond hard skills...things like how to think about my personal growth, how to think about the future, things like that. I think it opened my mind to some extent (Participant F).

The online workshops provided students opportunities to learn about themselves and explore practices that they may not have considered before.

I took that workshop because I really struggle with balancing school with life so I really would never in a million years have given myself the time to explore meditation. How great I felt after made it clear that it is worthwhile and I have made time for it (Participant C).

Many of the participants found the workshops to be a great learning experience and benefitted from the practical skills discussed to compliment and assist them in their studies.

Structural Description. The structural description also referred to as imaginative variation, is utilized to illustrate the "context or setting that influenced how the participants experienced the phenomenon" (Creswell, 2007, p. 61). As presented in the textual description above, it is deemed that the participants in the online workshops experienced a sense of community or camaraderie while in attendance, in addition to obtaining new professional skill sets as a result of the information presented at the workshops. It is believed that these experiences came into existence as a result of the online learning environment that the participants are engaged in while pursuing their studies. When reviewing the various scholastic programs in which the participants are enrolled in, namely, business administration, education, health sciences, and physiology, the primary method of content delivery is via asynchronous methods. In this mode of delivery, students receive a course package of print and other media such as textbooks, CD-ROMs, study guides, etc., in addition to computer-mediated communications, such as a learning management system (LMS) and e-mail. This mode of individualized study most often lacks real time or synchronous interactions with peers and instructors. Further to this, given that the programs are at the graduate level, the majority of the students will at some point in their studies, be engaged in thesis or dissertation writing. This aspect of the graduate study process can be a very reclusive and solitary endeavour, often without peer communication and intermittent interaction with advisors. Therefore, when the students were able to participate in the workshops in a live setting and given the opportunity to collaborate and interact with each other, many for the first time in their studies, they experienced this sense of inclusion and togetherness, the underlying theme of their workshop experience.

\section{Discussion}

The students who participated in this study experienced what those attending "brick and mortar" institutions get to experience daily, resulting in a more inclusive or complete graduate school experience. Key aspects that attributed to this complete experience included: informal access to other graduate students, contributions to their learning community, ongoing learning culture, opportunities for observation, and serendipitous conversation. The essence of the phenomenon was echoed in the comments made by the participants, stating; “I don't bump into other grad students 'in the halls' I think 
interactions such as these workshops help me feel part of a grad school culture" (Participant G) and "It was as if I was in a 'real' classroom which was a nice change from typing in the forums - bouncing ideas off each other, asking questions, and getting feedback right away" (Participant H). Irani, Wilson, Slough, and Rieger (2014) investigated graduate student experiences, both on and off campus, and found similar results. They concluded that technology-based distance graduate programs are not offering students the same quality of enrichment as their on-campus graduate counterparts. Their data indicated that the offcampus or distance students experienced increased social isolation from the lack of rich formal and informal interactions between faculty and peers.

For online graduate students involved in this phenomenological study, great value was placed on acquiring the professional skills that complement the hard skills conventionally learned within a disciplinary program and on the community development that emerges when students who are studying asynchronously are provided opportunities for live interaction amid fellow students. These findings highlight the fact that the online workshops filled the gap that the academic programs lacked, namely synchronous interaction and opportunities for professional development skill building. These shortcomings can be addressed with enhanced institutional online student services specifically tailored for online graduate students that not only include skill building in the form of workshops or tutorials, but must also encompass real time interaction in the form of group work or breakout sessions. There is a growing interest in online student support services - the services beyond the course - by a great many post-secondary institutions and interest in improving the quality and utilization of these services. According to the Contact North | Contact Nord's teachonline.ca (2016) website:

In order to have the best opportunity for success in their studies, online learners need access to more than course content and effective teaching. They need access to a wide range of support services that help them to engage with their institution and instructors, succeed in their studies, connect with each other, and make a successful transition to the workplace (para. 2).

Indeed, more tertiary institutions are realizing the importance of providing "the services beyond the course" for graduate students. The Council of Ontario Universities (2014) reports that seven of the large research universities in Ontario have formed the Ontario Consortium for Graduate Professional Skills and has developed and launched a professional development website for graduate students. The website www.mygradskills.ca provides access to 18 asynchronous units on topics such as resume writing, job searching, teaching and learning, and professional and academic communications. This is a great stride towards achieving the Canadian Association for Graduate Schools call for institutions to prioritize the delivery of formal learning opportunities via professional development workshops to their graduate students to facilitate workplace readiness. CAGS (2012) recommends that professional skill training opportunities for graduate students include transferable skills found in academics, such as research and teaching, in addition to other personal/interpersonal and career-related soft skills; leadership for graduate student professional studies should be undertaken by a School or Faculty of Graduate Studies department; provide access to graduate students via a single link in the Faculty of Graduate Studies homepage; include international and postdoctoral fellows to participate in the professional skills opportunities; provide recognition for participation in professional skill development activities; and ensure ongoing assessment of the activities and faculty buy-in. To accommodate the specific needs of 
online graduate learners, this list should also include opportunities for interactive, synchronous elements to foster community building and inclusiveness.

Sun (2014), states the following challenges face online graduate students: a) inability to follow the schedule and study regularly; b) difficulties in getting hold of classmates and finding a suitable time for group work; c) pairing/teaming up and working collaboratively; d) ensuring constant engagement with the class; e) keeping self-motivated and being a self-directed learner; and f) socializing. Future research should continue to explore the different experiences of graduate education and the unique challenges that exist for those studying virtually at this level of study. There needs to be further exploration into the appropriate mix of informal and formal academic scholarship, in addition to professional online learning opportunities to remedy any challenges and needs facing graduate students who study and learn online.

\section{Conclusion}

This study endeavoured to ascertain the overarching essence of the experiences of online graduate students who participated in online professional skill development workshops. As a result, it was discovered that the online graduates are seeking a full graduate experience that is readily available to their on-campus counterparts. The face-to-face ( $\mathrm{F} 2 \mathrm{~F})$ classroom environment provides the setting to build rapport with instructors and fellow students and where students have the luxury of interaction with peers or professors in the classroom and receiving immediate feedback. Online graduates forgo these personal experiences for the convenience of distance learning, however, the online workshops provided the participants a glimpse of what a graduate culture would be like by providing them with an opportunity for informal socialization, skill building, student and academic interaction, and community building. Overall, it was established that online graduate students are seeking colloquial learning communities, in addition to professional skill development as a formal opportunity to enhance their graduate education. The synchronous online environment where the skills development workshops were provided seemed quite effective in providing the supportive kind of environment that could contribute to graduate student development. Preparing graduate students for professional practice after graduation is of pedagogical value and "the lesson to be learned from this kind of research is that group work and socialization cannot be left to chance in online distance learning environments (and) activities have to be designed and carefully orchestrated for them to be effective" (Naidu, 2014, p. 3). Therefore, it is important to note the key role that the workshop facilitators played in engaging the participants during the workshops. Providing opportunities for participant involvement, not only with the content but also with each other, provided the opportunity for active learning and to develop a sense of community among the online graduate students, a facet not prevalent in most online graduate school experiences. Many more opportunities for graduate students to co-mingle in informal settings are needed to combat feelings of social isolation. The online skills building workshops provided in a supportive manner shows one successful venture down this path; however, it is evident that more effort is needed in providing online graduate students a more inclusive and complete graduate school experience. 


\section{References}

Allen, I. E., \& Seaman, J. (2007). Online nation. Five years of growth in online learning. Needham, Mass.: Sloan Consortium.

Allen, I. E., Seaman, J., Poulin, R., \& Straut, T. T. (2016). Online report card: Tracking online education in the United States. Retrieved from http://onlinelearningsurvey.com/reports/onlinereportcard.pdf

Andrews, J., \& Higson, H. (2008). Graduate employability 'soft skills' versus 'hard' business knowledge: A European study. Higher Education in Europe, 33(4), 411-422.

Canadian Association of Graduate Schools. (2008). Professional Skills Development for Graduate Students. Toronto: CAGS.

Canadian Association of Graduate Schools. (2012). Graduate Student Professional Development: Survey Recommendations. Retrieved from http://www.cags.ca/publications.php

Cain, D., Marrara, C., Pitre, P., \& Armour, S. (2003). Support services that matter: An exploration ofthe experience and needs of graduate students in a distance learning environment. Journal of Distance Education, 18(1), 42-56.

Cleveland-Innes, M., \& Ally, M. (2007). Learning to feel: Education, affective outcomes and the use of online teaching and learning. The European Journal of Open, Distance and E-Learning, 10(2). Retrieved from: http://www.eurodl.org/?article $=285$

Council of Graduate Schools and Educational Testing Service. (2012).

Pathways through graduate school and into careers. Report from the Commission on Pathways Through Graduate School and Into Careers. Princeton, NJ: Educational Testing Service. Retrieved from http://www.pathwaysreport.org/rsc/pdf/19089 PathwaysRept Links.pdf

Contact North | Contact Nord. (2016). How to build effective online learner support services. Retrieved from http://teachonline.ca/sites/default/files/toolstrends/downloads/build_effective_learner_suppor t.pdf

Council of Ontario Universities. (2014, September 08). New online professional development training - mygradskills.ca - tailor-made for busy graduate students. Retrieved from http://www.cou.on.ca/news/media-releases/cou/new-online-professional-developmenttraining---myg

Creswell, J. W. (2007). Qualitative inquiry and research design: Choosing among five 
approaches. (2nd Ed.). Thousand Oaks, CA: Sage Publishing.

De Villiers, R. (2010). The incorporation of soft skills into accounting curricula: Preparing accounting graduates for their unpredictable futures. Meditari Accountancy Research, 18(2), 1-22.

Dvorak, P. (2007). MBA programs hone “soft skills.” The Wall Street Journal, p. B3.

Hawranik, P., \& Chernish, R. (2009). Graduate Student Educational and Professional Development Final Report. Faculty of Graduate Studies: Athabasca University.

Hurst, D., Cleveland-Innes, M, Hawranik, P., \& Gauvreau, S. (2013). Online graduate student identity and professional skills development, Canadian Journal of Higher Education, 43(3), 36-55. Retrieved from http://ojs.library.ubc.ca/index.php/cjhe/article/view/184674/184310

Hurst, D., \& Thomas, J. (2008). Developing team skills and accomplishing team projects online. In T. Anderson (Ed.), Theory and practice of online learning, (441-472). Athabasca, Alberta: Athabasca University Press.

Irani, T. A., Wilson, S. B., Slough, D. L., \& Rieger, M. (2014). Graduate student experiences on-and offcampus: Social connectedness and perceived isolation. International Journal of E-Learning \& Distance Education, 28(1).

Lawrence, D. (2012, November 5). In hard times, soft skills taught more in B-school. The Globe and Mail. Retrieved from http://www.theglobeandmail.com/report-on-business/careers/businesseducation/in-hard-times-soft-skills-taught-more-in-b-school/article4929262/

Naidu, S. (2014). In search of "what works" in online and distance education. Distance Education, 35(1), 1-3.

Razali, M., Syamimi, N., \& Yahya, N. (2010). Blended learning: Overcome the weaknesses of learning and traditional approach. edupress 2010. Retrieved from http://eprints.utm.my/14929/

Rubin, R. S., \& Dierdorff, E. C. (2009). How relevant is the MBA? Assessing the alignment of required curricula and required managerial competencies. Academy of Management Learning \& Education, 8(2), 208-224.

Sun, S. (2014) Learner perspectives on fully online language learning, Distance Education, 35(1), 18-42.

University of Saskatchewan. (2016). Professional skills for graduate students workshops. Retrieved from https://www.usask.ca/ulc/workshops/psgrad

Winter, R. (2002). An executive MBA program in business engineering: A curriculum focusing on change. Journal of Information Technology Education, 1(4), 279-288. 
York University. (2016). Graduate profession skills. Retrieved from http://gradstudies.yorku.ca/current-students/enhancing-your-experience/graduateprofessional-skills/ 


\section{Focus Group Questions}

\section{Appendix A}

Specifics: Motivation for participating in online skill building workshops?

1. What was your motivation for taking part in this research project? Why do you think more women than men participated?

2. As an online graduate student are you different from others studying in a traditional format? Do you feel that you have different responsibilities or challenges to deal with beyond what students studying in traditional face-to-face environments have?

3. What did you find to be the strengths and limitations of attending professional skills workshops? How did the workshops impact you as a participant? What did you get out of them? What more were you hoping for?

Change Journey?

4. Did the workshops have any influence on you? Did they contribute to your change journey as an individual? If so what ways? Have the workshops had any impact on how you understand your role as a graduate student, scholar? How can online workshops impact graduate students with respect to their current and future positions of employment, progress in academic programs, managing their work/study/personal lives?

5. Did you feel the professional skills targeted during the workshops were developed? If so, can such skill building impact your current coursework, relationships, perception of graduate student experience? As a result of attending the workshop, are you any better prepared to work in an academic environment? Interact with your peers as a result of the workshops? If not, what would have been a better way to develop skills?

Full Graduate Student Experience?

6. One of our research objectives was to learn about the impact that skill building workshops may have in contributing to a full graduate student experience. What do you consider to be a 'full' graduate experience? Have you had one at AU? Describe?

7. Which topics were of greatest interest to you? How could we have better met your needs/interests? What other topics would you recommend for workshops to assist graduate students in their scholarly development? Receive a 'full' graduate experience?

8. Will you keep in touch with other workshop participants? Was there any learning shared during the workshops that went beyond the workshop content? If so, can you describe the content as well as the conversation that took place where it was shared?

Community Building?

9. Did attending the workshop make you feel that you were building a community? Did you at any time begin to feel a sense of community building with other graduate students during any of the 
workshops? If so, when did this begin to occur for you? If not, what could have assisted with community building? What else could have been done to enhance community building?

10. With respect to the community that was developing as a result of the workshops - did you feel encouraged to share ideas, concerns during the workshop with your peers? Did the learning environment feel safe and encouraging to you? If yes, please describe your experience of it, if no, what could have been done differently? What else can AU do to improve graduate student community?

Summary thoughts?

11. Would you recommend that your colleagues attend online workshops as part of their educational experience? In what other ways can AU help influence your graduate student experience?

12. Do you have any questions for us, or other contributions, thoughts that you wish to make that will help us understand your point of view on this topic? 


\section{Appendix B}

\section{Significant Statements from Focus Group}

\section{Table 1}

\begin{tabular}{|c|c|}
\hline Significant Statements & Formulated Meaning \\
\hline $\begin{array}{l}\text { I think what helped me in the workshop were the ability to link } \\
\text { with other people who were having similar types of experiences } \\
\text { along the way, feeling like here I am, what am I doing in this } \\
\text { program? And other people expressing those types feelings as } \\
\text { well, it certainly took the isolation out of the what I was feeling } \\
\text { in the } 610 \text { course I was taking...So this workshop came at the } \\
\text { right time to help me to connect with others. }\end{array}$ & $\begin{array}{l}\text { Lack of synchronous opportunities in } \\
\text { the graduate programming. Students } \\
\text { are looking to form relationships with } \\
\text { others to share and compare } \\
\text { experiences. }\end{array}$ \\
\hline $\begin{array}{l}\text { I agree with the comment about reducing the isolation. It would } \\
\text { be nice to have a forum to 'connect' with other students. ie: } \\
\text { support, ask questions, etc. }\end{array}$ & $\begin{array}{l}\text { Students experience feelings of } \\
\text { isolation and need to combat this with } \\
\text { opportunities to connect with others. }\end{array}$ \\
\hline $\begin{array}{l}\text { I wish the academic writing workshop would have been in } \\
\text { more depth -- I felt like some of it was a bit rudimentary -- e.g. } \\
\text { paragraph development }\end{array}$ & $\begin{array}{l}\text { Online graduate students require more } \\
\text { advanced material with regards to } \\
\text { academic writing skill development. }\end{array}$ \\
\hline $\begin{array}{l}\text { Yes the workshop had an influence. Ifeel the writing workshop } \\
\text { has provided me with additional skills to write more } \\
\text { academically. }\end{array}$ & $\begin{array}{l}\text { Providing professional skill } \\
\text { development workshops enabled } \\
\text { online graduate students to glean } \\
\text { various skills. }\end{array}$ \\
\hline $\begin{array}{l}\text { In addition, the meditation workshop has stuck with me in that } \\
\text { I try harder to stay within a balanced life. }\end{array}$ & $\begin{array}{l}\text { Online graduate students are taking } \\
\text { away valuable skills from the sessions. }\end{array}$ \\
\hline $\begin{array}{l}\text { I liked the opportunity to meet other grad students in other } \\
\text { disciplines and areas and see we had similar concerns. It was } \\
\text { kind of an intangible, but it was exciting being in a web } \\
\text { conference with a range of people doing the same kind of work } \\
\text { and imaging being with those people in convocation and things } \\
\text { like that. }\end{array}$ & $\begin{array}{l}\text { Students are expressing their need to } \\
\text { meet and converse with others. }\end{array}$ \\
\hline $\begin{array}{l}\text { I don't bump into other grad students "in the halls" I think } \\
\text { interactions such as these workshops help me feel part of a grad } \\
\text { school culture }\end{array}$ & $\begin{array}{l}\text { Providing online graduate students a } \\
\text { chance to interact with one another } \\
\text { has simulated feelings of a full } \\
\text { graduate experience. }\end{array}$ \\
\hline $\begin{array}{l}\text { I liked being able to break off into smaller groups to work with } \\
\text { others during the career planning workshop. }\end{array}$ & $\begin{array}{l}\text { Students enjoy personal interaction } \\
\text { with others, especially when learning } \\
\text { at a distance can be an isolating } \\
\text { experience. }\end{array}$ \\
\hline I liked meeting students from other programs. & $\begin{array}{l}\text { Online graduates have little } \\
\text { opportunity to socialize with others in } \\
\text { different programs. }\end{array}$ \\
\hline $\begin{array}{l}\text { I like the comment about grad school culture- like hanging } \\
\text { around in the campus! }\end{array}$ & $\begin{array}{l}\text { Providing online graduate students a } \\
\text { chance to interact with one another } \\
\text { has simulated feelings of a full } \\
\text { graduate experience. }\end{array}$ \\
\hline So for sure, the idea of the workshops at the beginning $\mathrm{w}$ & Students expressed the need for such \\
\hline
\end{tabular}




\begin{tabular}{|c|c|}
\hline $\begin{array}{l}\text { have helped with that and would help people like me, unless I } \\
\text { am an anomaly, feel more connected. }\end{array}$ & $\begin{array}{l}\text { skill building workshops to be offered } \\
\text { at the beginning of their programs to } \\
\text { aid in building communities with } \\
\text { other students. }\end{array}$ \\
\hline $\begin{array}{l}\text { It was as if I was in a "real" classroom which was a nice change } \\
\text { from typing in the forums - bouncing ideas off each other, } \\
\text { asking questions, and getting feedback right away. }\end{array}$ & $\begin{array}{l}\text { The social interaction in the } \\
\text { workshops was a major positive for } \\
\text { many students who study } \\
\text { asynchronously. Students are looking } \\
\text { for reinforcement from others. }\end{array}$ \\
\hline Another big plus was the real time format vs. asynchronous. & $\begin{array}{l}\text { Students are indicating their } \\
\text { preference for synchronous delivery } \\
\text { methods. }\end{array}$ \\
\hline $\begin{array}{l}\text { I also really benefitted from talking to others who have work } \\
\text { experience in the field and who were able to give some advice } \\
\text { in the small group portion of the career workshop. }\end{array}$ & $\begin{array}{l}\text { Students are gleaning field related } \\
\text { information from classmates in real } \\
\text { time. }\end{array}$ \\
\hline $\begin{array}{l}\text { I thought if I could join the workshop and not feel like I am } \\
\text { stupid because I don't know how to do some of these things in } \\
\text { particular ways, I felt the workshops were a very safe place to } \\
\text { explore some of things that I need to write my thesis. } \\
\text { The workshops felt very safe, comfortable, and open to discuss } \\
\text { concerns and ask questions. I only attended } 1 \text { of them. }\end{array}$ & $\begin{array}{l}\text { Providing a safe environment for } \\
\text { students to explore thoughts and } \\
\text { perceptions is key for online } \\
\text { workshops. }\end{array}$ \\
\hline $\begin{array}{l}\text { I feel like I've had the opportunity to work with and learn } \\
\text { alongside some very interesting and accomplished students. } \\
\text { That's been a great experience. }\end{array}$ & $\begin{array}{l}\text { Students are eager to learn from each } \\
\text { other's practical knowledge and } \\
\text { experiences. }\end{array}$ \\
\hline $\begin{array}{l}\text { I learnt something beyond my course work, beyond my courses } \\
\text { in the MBA program, beyond hard skills...things like how to } \\
\text { think about my personal growth, how to think about the future, } \\
\text { things like that. I think it opened my mind to some extent. }\end{array}$ & $\begin{array}{l}\text { Students acknowledge the importance } \\
\text { of developing competencies outside of } \\
\text { the academic realm. }\end{array}$ \\
\hline $\begin{array}{l}\text { I would say from the first time we were together there was a real } \\
\text { connect for me, um, with other people, it was a really positive. }\end{array}$ & $\begin{array}{l}\text { Students found interaction within the } \\
\text { workshops to be a positive experience. }\end{array}$ \\
\hline $\begin{array}{l}\text { I am still finding the web environment a little } \\
\text { disjointed...perhaps it is a learning curve on the technology, but } \\
\text { I find it still not as dynamic as f2f interaction. }\end{array}$ & $\begin{array}{l}\text { Some students find online learning not } \\
\text { as engaging as face-to-face learning. }\end{array}$ \\
\hline $\begin{array}{l}\text { For me being a part of these workshops made me realize that I } \\
\text { am part of a bigger part of the community of people with all } \\
\text { kinds of skills and abilities and help that I can access. }\end{array}$ & $\begin{array}{l}\text { The workshops aided in facilitating a } \\
\text { shared sense of community by } \\
\text { enabling peers to communicate and } \\
\text { support one another in distributed } \\
\text { space. }\end{array}$ \\
\hline $\begin{array}{l}\text { I think I learned more soft skills and the workshops helped my } \\
\text { personal growth. }\end{array}$ & $\begin{array}{l}\text { Students are able to glean soft skills by } \\
\text { attending online workshops. }\end{array}$ \\
\hline $\begin{array}{l}\text { Helped me to reorient my writing. } \\
\text { Clarity for me on writing for the program was helpful, my post } \\
\text { course marks are up and my time to write the papers is down. } \\
\text { Better skills and targeting, I think. }\end{array}$ & $\begin{array}{l}\text { Attending an Academic Writing } \\
\text { workshop helped students improve } \\
\text { writing skills. }\end{array}$ \\
\hline
\end{tabular}




\begin{tabular}{|c|c|}
\hline $\begin{array}{l}\text { I am using the referencing section from the academic writing } \\
\text { workshop. } \\
\text { The information learned in APA will continue to 'haunt' me as I } \\
\text { write each assignment and paper. This is all a good thing. }\end{array}$ & $\begin{array}{l}\text { Students are pulling practical and } \\
\text { applicable skills from the Academic } \\
\text { writing workshops. }\end{array}$ \\
\hline $\begin{array}{l}\text { I took that workshop because I really struggle with balancing } \\
\text { school with life so I really would never in a million years have } \\
\text { given myself the time to explore meditation. How great I felt } \\
\text { after made it clear that it is worthwhile and I have made time } \\
\text { for it. }\end{array}$ & $\begin{array}{l}\text { The online workshops provided } \\
\text { students opportunities to learn about } \\
\text { themselves and explore practices that } \\
\text { they may not have considered before. }\end{array}$ \\
\hline $\begin{array}{l}\text { I think that when you're looking at skills and insights, that it } \\
\text { would have been nice if a group of us, that were interested, could } \\
\text { have stayed connected and continued working on the skills of } \\
\text { that session. The isolation of DE can be really debilitating and to } \\
\text { have formed some kind of collegial growth session would have } \\
\text { been nice for us to expand that. } \\
\text { more time. like others have suggested, making them a series } \\
\text { rather than a one-off would give more opportunity for a more } \\
\text { substantial impact. } \\
\text { I agree, having a couple of these per semester would be great } \\
\text { I look forward to attending workshops in the future! }\end{array}$ & $\begin{array}{l}\text { There seems to be a demand for } \\
\text { opportunities for skill development } \\
\text { and online interaction for online } \\
\text { graduates. Students think it would } \\
\text { benefit them to have workshops } \\
\text { offered on a regular basis. }\end{array}$ \\
\hline $\begin{array}{l}\text { I wish there had of been more time for reflection during the } \\
\text { workshops -- it was difficult to respond take part in some of the } \\
\text { discussions when things were moving so fast at times. }\end{array}$ & $\begin{array}{l}\text { Skills workshops need to not only } \\
\text { focus on content, but allow time for } \\
\text { students to interact and participate. }\end{array}$ \\
\hline Thank-you for providing such great opportunities to us. & $\begin{array}{l}\text { Students were grateful to have skill } \\
\text { developing workshops made available } \\
\text { to them. }\end{array}$ \\
\hline
\end{tabular}

* The comments in italics represent responses typed in the chat box of the session. 